\title{
OVID'S EXILIC VOCABULARY ${ }^{1}$
}

\author{
$J-M$ Claassen (University of Stellenbosch)
}

\section{Introduction}

Ovid's artistry with words has been called "logodaedaly", creative word magic. ${ }^{2}$ His "painting with words" lies partly in a controlled use of synonyms. ${ }^{3}$ The poet's originality in creating new words has also been much commented upon. ${ }^{4}$ His artistry with words when in exile offers continued pleasure. Words were of paramount importance for an exiled poet who was reaching out to his friends and to the enemy who exiled him. In the process he created a word-portrait of himself as suppliant; as Downing (1993:13) puts it: "The author makes a self, while the self makes a book of the self." Ovid's readership in Rome would have been familiar with the whole of his earlier oeuvre as context for a particular diction. In the context of his exile, the poet's choice of words and the uses to which he put his vocabulary were a powerful means of influencing public thought. Augustus, as very particular member of the more general readership, had to be persuaded that his previous works were innocuous, if ever the exile were to be allowed to return. At the same time the poet seems to have sought a means of criticizing the emperor without antagonising him.

Nagle (1980:61-68) argues that a large part of the "specialized vocabulary" of Ovid's exilic works is really an erotic elegiac vocabulary which the exiled poet has adapted to his circumstances, in other words, she postulates a (perhaps unsurprising) intertextual relationship between the poet's early and late works. The reason for this she ascribes to his search for an appropriate medium to express exile as poetic death, and when "he realized the similarity of the poeta relegatus and the exclusus amator, ...he hit upon erotic elegy as providing the closest approximation to his new situation" (1980:70; my emphasis). Hence, for Nagle, his adoption of erotic themes and vocabulary. Her unnuanced statement has prompted me to verify the degree to which this may be so, and to conjecture on possible other reasons for the phenomenon, if proven such. Of possible importance is the original provenance of the traditional "erotic" vocabulary. Many of these words are not essentially related to aspects of love, but come from different spheres, notably politics, friendship and the law. In the

1 I gratefully acknowledge the encouragement of Professor Elaine Fantham of Princeton University, and the comments by two anonymous readers on earlier drafts of this paper, relayed to me Dr Stephen Heyworth and Prof Philip A Stadter, whose advice was much appreciated, even if I did not always take it. I have tried studiously to follow the advice of Akroterion's two readers. I wish further to thank the Division of Research Development at Stellenbosch University for subvention of a research assistant, and Maridien Schneider for her admirable functioning in that capacity, and Corné Janse van Rensburg for excellent editing.

2 Cf. e.g. Lateiner 1990 on Ovid's verbal mimesis.

3 The exilic poetry has about ten different terms for the sea: mare, fluctus, fretum, aquae, undae, aequora, montes aquarum, Oceanus, pontus, pelagus, so Micu 1981.

4 Cf. Seneca's famous story (Controv. 2.2.12) about the "portmanteau words". See Kenney (1973) on unusual compounds. 
hands of both Ovid and his predecessors, these had been moved into the erotic sphere. Perhaps the exilic context offered our poet a chance to realign the semantic implications of these words, thereby perhaps also influencing his readers' perception of their previous "erotic" use.

Conte (1994:41-65) has shown that Ovidian love poetry deconstructs the premises of elegy; this paper will examine how the exilic works reconstruct common elegiac vocabulary. The process of intertextuality, in the words of Vincent (1994) "relates a work of art with other works...[It is] a form of reference when...a text presupposes another...and...the latter provides the former with the means of interpreting it." Ovid's re-use of vocabulary from the erotic sphere redirects the reader's interpretation of its earlier usage. ${ }^{5}$ With full awareness that "auctorial intention" is difficult to establish, I shall nevertheless allow myself to speculate about possible deliberate reinterpretation of words by the author in order retrospectively to influence his readers' reception of his earlier works.

Obviously, attention to the functioning of a poet's words in context is the only way to deal with his poetry; that is, what the poet says can only be read from how he says it. Equally so, while only attentive reading of the poems, in the order that they were composed (see chronology below), will discover shifts in the exile's attitude and thought, this process can sometimes be aided by attention to quantification, if only to delineate patterns in selection of topics and the tools the poet employs when dealing with them.

So, context is needed to illuminate usage, but awarenes of a general trend in the usage of a particular word will sometimes guide the reader towards a particular reading within a particular context. This is of specific use in judging of possible irony or slippage between what is said and what is implied. In an important article, Ahl (1984) stresses that covert criticism of a powerful political figure was deemed safe by the ancients, as long as an innocent meaning could also be read into the words. Where Ovid's poetic transgression had been given a political colour by Augustus, he may have felt the need to give new stress to the innocence of the vocabulary he had formerly employed in erotic contexts, but perhaps also a need to continue with his heady fun.

The paper will therefore examine sets of semantically related words employed by the poet in the Tristia and Epistolae ex Ponto ${ }^{6}$ including reuse in a different setting of words made familiar in a previously erotic context, by both the poet and other authors. Predominant semantic sets in Ovid's exilic works will be identified, and the chronological occurrence of the most prominent words from each set will be briefly explored in order to map the exile's shifts in his use of vocabulary within the eight years of exile. This will have three functions: first, it can be employed as a reference tool to aid any reader's critical judgement of particular occurrences by

$5 \quad$ Kenney's Introduction in Melville 1992 spells out Ovidian imaginative interaction with his own earlier works. Sharrock (1995) finds the opposite process in Amores 3.7, where euphemism acts as a "loaded form of polysemy".

6 For the sake of brevity I shall hereafter use the initials " $T$ " and " $P$ " respectively to refer to the Tristia and Epistulae ex Ponto, particularly in references to particular books or lines. 
awareness of the trend of the exile's thought, and second, it can be used to judge either change or consistency in importance of particular topics or themes (as represented by these words) over time. Finally, frequency of use of certain words from earlier works in a changed context may further indicate the need to revise the value readers should place on the poet's earlier use of such words. That means that within this patterning a conscious reworking or redirection of these tools may become discernible.

\section{Overview of premises and method}

\section{Choice of vocabulary}

Nagle's assertion that most of the "specialized" vocabulary of the exilic works was adapted from erotic elegy is only partly true. Many words common to the exilic works and the erotic elegiac genre originally derive from other semantic spheres ${ }^{7}$ and were adapted to specialized elegiac use by Ovid's predecessors. Ovid is adept at using familiar words in new settings, particularly in an erotic context, where double entendre and various levels of meaning are often discernible. ${ }^{8}$ In the exilic works a seemingly conscious system of "de-punning" both evokes earlier elegiac use and restores words to their original semantic sets (Conte 1994:143), thereby inverting the elegiac tradition (which is itself an inversion of "real life").

\section{Chronology}

The chronological structure of the exilic corpus is important. Critics sometimes fail to distinguish between the tone of poems from the first year of Ovid's wanderings and those from the nebulous last years of his exile. Chronological examination of the exilic works shows changes in style, attitude and tonality (Claassen 1992). The exilic poems can be dated fairly certainly from internal evidence (the poet's references to his own age, to Augustus' death and to historically verifiable events) and the limit imposed by the poet's death. ${ }^{9}$ The poetry traditionally was received in an order presumably arranged by the poet himself (with the possible exception of $P 4$, perhaps collected posthumously). Ovid was always a prodigious worker, and his output increased at about the turn of our era but declined after about $A D$ 14. During the time of exile Ovid's poetic output fluctuated. In the first few months he produced $T 1$ and $T 2$, over a thousand verses, some apparently produced while still on his journey to Tomis. P4, with a smaller output of only 930 verses, appears to represent four years' output. For the purpose of analyzing possible changing usage of vocabulary, the exilic oeuvre may conveniently be divided into five chronological (rather than thematic) phases: ${ }^{10}$

7 Conte (1994:41) refers to a discomfort aroused by the tension between "irreconcilable rhetorics".

8 Pichon (1902) stresses that Ovid never uses obscene words. Green (1981) lists as the most common "doublets": membrum, testis, nervus, latus, coire, miscere, surgere, cadere, iacere. Cf. Adams 1982:224-225.

9 My datings are based on Pippidi 1972, correlated with Kenney in Melville 1992: xi.

10 For detailed arguments grounding this division, see Claassen 1986, Section 4.1. 
Phase 1:December AD 9 to about March AD 10: $T 1$ and T2, 1280 verses;

Phase 2:March AD 10 to about February AD 12: T3 and T4, 1466 verses;

Phase 3:March AD 12 to about January AD 13: T5 (possibly also parts of $P 1$ and the Ibis), 800 verses; 11

Phase 4:October AD 12 to about December AD 13: $P 1$ - P3, 2264 verses;

Phase 5:From about January AD 14 to the death of the exile: P4, totalling 930 verses. ${ }^{12}$

\section{Method}

The distribution over these five phases of key terms will be discussed, and relative frequency will be established by statistical means, that is, number of occurrences per hundred lines of verse will be used as a comparative tool. The table (Addendum at the end of this paper) gives a summary of frequencies of key words in the Tristia and Epistolae ex Ponto, and a statistical interpretation of relative increase or decrease of occurrences within the course of the poet's years of exile. ${ }^{13}$

\section{Semantics}

What moderns would consider as "false etymology" represented for the ancients a valid connection between disparate words. For the Epicureans, there was an inherent relationship between a thing and the word for it. Dissimilar objects with similarsounding names therefore had some intrinsic relationship. This similarity need not only be that of homophones or homonyms. Communality of the elements of two words could imply a relationship, as with what Snyder (1980:40) terms Lucretius' "verbal atomism" in word groups like: lignis - ignis; mater - materies; crescentesque - noscere - grandescere - certus - secreta etc. ${ }^{14}$ The Epicurean assumption of an intrinsic relationship between words with common elements seems to have been widely influential. Ahl (1986) has shown the importance of such soundplay in the interpretaion of wordplay with Ovid and other poets.

11 The Ibis is a poem of invective and although it is exilic, I have chosen to omit it for consideration here, as its generic nature differs so widely from the most of the Tristia and Ex Ponto. Both the Metamorphoses and Fast $i$ received at least their final reworking during the poet's exile, but have for similar reasons been discounted here, except as an occasional basis for comparison.

12 Order of composition within each phase is not fixed, and the "collections" $(T 1, P 1-3)$ each have a prologue and epilogue probably composed after the body of a particular collection. See Helzle 1988 passim. The Ibis was probably concurrently composed with the poems of Phase 3, which may explain an apparent "small" output of 800 verses in a year, after 1466 verses in the previous. Probable sequential overlap of parts of Phases 3 and 4 would partly account for an apparent leap in output to 2264 verses during Phase 4 . Conjectures about the composition or revision of the Fasti and the double epistles should also be taken into account, despite Kenney's comments in PLLS 8 (1995: $206 \mathrm{n} .84$ ), quoted by one of my anonymous readers.

13 Figures are reworked to give relative frequency per hundred verses in each phase. See Claassen 1986, Section 5.2 for detailed discussion.

14 Thoroughly discussed in relation to Ovid by Ahl (1986), against whom Cameron (1995) argues that the modern distinction between upper and lower case influences interpretations. 
Where possible, therefore, attention will be paid to the often fanciful ancient etymologies of words (usefully collected by Maltby 1991) in order to ascertain what weight certain words would have carried for our author and his contemporary readers. With those etymologies that post-date Ovid, particular circumspection is needed, but it is not unjustified to postulate an etymological tradition, or to guess that Ovid would have subscribed to popular interpretations, even if these were recorded only much later.

\section{The interpretative process}

The following is an illustration of how awareness of frequency and trend of usage may influence the contextual reading of a particular word. Turba is a favourite Ovidian word, taking colour from its often ambiguous context. Its primary sense in Lewis and Short is negative: turmoil, hubbub, uproar, disorder, tumult, commotion, disturbance of a crowd of people, and only the secondary meaning is more neutral: crowd, throng, multitude, mob, etc. Eichert (1904) has as first meaning ungeordenete Menge, Haufe, Schwarm, Schar, as secondary meaning Getümmel, Gewühl. Hellegouarc'h (1963) calls it "political group, following". ${ }^{15}$ The word occurs in the exilic poems altogether 35 times. Of these 18 have an apparently positive or neutral connotation, "following", "large group", usually in a civic sense, 13 are negative with the connotation of unruly mob, and in three cases the value of the word is unclear. ${ }^{16}$ There is no particular variation through time; the word is, however, always negative when applied to the inhabitants of the Euxine area, or, metaphorically, to the exile's ills, whereas allusions to civic activities in Rome are positive. Awareness of its use in negative contexts, then, influences interpretation of apparently positive instances.

In $T 2.88$ the exile reproaches the emperor: est vultus turba secuta tuos. We know by now that the emperor was angry with the exiled poet. The meaning of this line may simply be "your followers watched your expression", but awareness that the majority of the occurrences of turba in the exilic works is negative, gives the reader pause. The line may also mean "that mob followed your (angry) expression (and reviled me too)". Even more uncertain is the emotional "feel" of turba in T3.1.77-78 di precor, atque adeo - neque enim mihi turba roganda est! / Caesar, ades voto, maxime dive, meo. ${ }^{17}$ The question is how much irony is to be read into this particular allusion. The exile prays directly to Augustus, and adds in an aside, "for I don't have to apply to a whole mob of gods". The observation may be read as a compliment: "you Augustus are paramount among your following of (minor) gods", while, however, at the same time it suggests the extent to which Augustus has superseded the gods in Roman civic and religious life. Similarly, occurrence of the word in

15 Cf. Zumwalt 1977; Ferguson 1978.

16 Positive: T3.2.4 vos Pierides... / docta... turba; T5.3.47 vos quoque, consortes studii pia turba, poetae; P4.9.6 et fiam turbae pars ego nulla tuae; P4.9.17 dumque latus sancti cingit tibi turba senatus. Negative: T5.6.41 quam multae... / tam me circumstant densorum turba malorum; T5.10.28 mixta facit Graecis barbara turba metum.

17 Perhaps an echo of Cicero Nat. D. 1.15.39: turba ignotorum deorum, which Ovid has echoed before: F2.668 deorum / cuncta Iovi cessit turba. 
T4.1.54, namque deorum / cetera cum magno Caesare turba facit invites a negative interpretation, if only in the sense that it again stresses the degree to which the emperor has assumed the status and role of a god.

\section{Specialized vocabulary}

Nagle (1980:63-64, and n.112) lists the following as examples of "erotic diction" employed in the exilic works: miser, me miserum, tristis, infelix, maestus, sollicitus, curae, mala, labores, dolores, amarus, lacrimae, fletus, metus, luctus, taedia, desiderium, cupido, carere, spes, improbus, crudelis, durus, saevus, mitis, lenis, ira laesi dei, crimen, scelus, culpa, error, poena, deus, numen, supplex, preces, vota, auxilium, solacia, levare, fides, memor, immemor, utilitas. Rather strangely, she does not list the obvious, amor, amica and amicitia. ${ }^{18}$ A glance at Deferrari et al. (1969) or a search through the PHI CD ROM (1991) will confirm that these words appear frequently in both the erotic poems and in the exilic oeuvre. Nagle controlled her list against Pichon's (1902) very thorough listing of the vocabulary of erotic elegy. As Videau-Delibes (1991:13) shows, however, Nagle pays scant attention to nuancing or progression in the use of these words. Pichon lists his words in different categories, under their original semantic provenances, showing that military, political, medical, literary, legal, religious, nautical, hunting and fishing terms had been adapted to erotic use. Pichon lists words unique to Ovid, but also words which in Propertius had a negative meaning, which Ovid gives a positive connotation.

Pichon's erotically adapted words are far more specifically "erotic" than the words (many denoting suffering) listed by Nagle. His list compares well with the Roman political terminology collected by Hellegouarc'h (1963). Words connected with the exile's misdeed have a legal provenance. Words from the political sphere relate particularly to the merging of the language of statesmanship with the language of friendship, and to specialized rhetorical and didactic uses. Some words from these various sets are used so consistently within the exilic context, that they may be called the "specialized vocabulary of exile", and of these, some (in particular words denoting misery and longing or expressing distance) may by their nature be termed "naturally exilic".

\section{"Political" words}

"Political" words the poet employs are turba ${ }^{19}$ clementia, iustitia, moderatus, nobilitas, pater patriae, princeps, prohibere, vetare, imperium, salus, triumphus, pax, hostis, infestus, eques. ${ }^{20}$ Cognates and derivatives can usually be considered with these key words.

18 Purnelle-Simart and Purnelle (1987) list amor as 29th in absolute order of frequency in Ovid's elegiacs, amo as 40th. The two words are, with puella (19th) the only clearly elegiac words in a list predictably beginning with sum, -que, et, qui, in.

19 Discussed above, as an illustration of nuancing of meaning.

20 Cf. Doblhofer 1978; Benedum 1967; and Eichert 1904. 
Some of these words are clearly positive, and are frequent enough to warrant phase-by-phase comparison. Hellegouarc'h lists clementia, iustitia and moderatio as characteristics of the Roman political man, his clipeus virtutis, in Cicero's phrase. In Res Gestae 34.2 Augustus connects these terms, together with his virtus and pietas, when recounting the celebration of his assumption of his new name in 27 by the award of a civic crown and the setting of a golden shield in the Curia Julia. The exile dutifully applies the words to Augustus, but also to others, including his friends. ${ }^{21}$

Clementia, the characteristic Augustus particularly prided himself on exhibiting, may be termed "kindness", mercy beyond deserts. It (or its cognate clemens/clementissimus) occurs only once each elsewhere Ovid's works, in both cases in the Metamorphoses, and only ten times in the exilic poetry: once in Phase 1, four times in Phase 2, once in Phase 3, three times in Phase 4, and once only in Phase 5. The relative infrequency of a term one might have expected the exile to use often in pleas for recall is perhaps significant. The last occurrence is applied to the exile's patron Sextus Pompeius, dedicatee of the last book. The implication of the accompanying perfect participle territa is that demonstration of aid can be dangerous for the person exhibiting clementia:

\section{nunc quoque nil subitis clementia territa fatis auxilium vitae fert...}

Your constancy, quite undeterred by my sudden downfall, still brings-and will go on bringing - aid to my life...

(P4.1.25; trans. Green 1994)

Iustitia, another of Augustus' vaunted characteristics, is not frequent; its cognate iustus $(-a,-u m)$ very frequent in the Ovidian oeuvre as a whole (some 71 occurrences in all). ${ }^{22}$ Often the word iustus has a neutral sense, as "justifiable", "good", but its context may relate to either a negative or a positive judgement by the exile. In the first phase iustus has a positive context at T1.3.62, utraque iusta mora est (a good reason to delay) and at $T 2.29$, illa quidem iusta est (and that is justified) it refers to the emperor's anger, conceding that there was some reason for this emotion. Of four occurrences in Phases 2 and 3, only one refers to the emperor. The others can be discounted. In Phase 4 five references out of eight acknowledge the "justness" of the emperor's attitude, and then the topic is dropped. In Phase 5 iusta refers to complaints, by the poet or his friends, as being "justified".

The next characteristic of a good ruler, moderatio, the setting of a measure, is precluded by its prosody from use in elegiacs. Moderatus is infrequent, occurring once in each of the first three phases, twice relating to the emperor. The fourth phase

21 Bland allusion to the emperor's clementia (e.g. T4.4.53, quanta in Augusto clementia..., "so much mercy is to be found in Augustus") may indicate wishful induction of a particular virtue by the poet, as with Seneca's De Clementia, aimed at the young Nero.

22 Maltby 1991 s.v. ius collects ancient etymologies relating the word to its cognates, without speculation about origins (Ulp. Dig. 1.1.1; Isid. Orig. 5.25.3); Lewis and Short give Sanscrit yu-, "to join"; this may indicate a development of the concept within primitive political thought from "connection" to something like "agreement on what is right". 
has moderatus twice and moderor, as applied to the emperor, once, as in P3.6.23-24: principe nec nostro deus est moderatior ullus / Iustitia vires temperat ille suas ("and no god is more moderate than our Princeps: he tempers his powers with justice"), where flattering appeal appears to acknowledge guilt.

Augustus' pride in the new title pater patriae, conferred in $2 \mathrm{BC}$ (as noted in $R G 35$ ), is twice acknowledged in apostrophe during the course of $T 2$ (181, parce, pater patriae... and again at v.574). A third reference acknowledges him as patriae rector...paterque (T2.39). Pater patriae and the semantically related parens occur altogether eleven times throughout the exilic works. Significantly, Augustus is reminded at T4.4.13 that as pater patriae he had suffered himself "to be read" (legi) in Ovid's song. No virtues, other than "saving the state" or physical parenthood, are ascribed to Augustus as pater. In the fourth phase two occurrences allude in an elliptic phrase to Augustus" "double parentage" -of both the state and of Tiberius. ${ }^{23}$ Parens appears once as the equivalent of "father of the state" $(T 2.157$, per patriam, quae te tuta et secura parente est, "by the Fatherland, which, with you as its parent, is safe and secure"). Isidorus' (correct) etymology (Orig. 9.5.4, parentes quasi parientes $)^{24}$ if known to Ovid, would have enhanced the flattery here involved, as it stresses the emperor's having produced a reborn state. Yet generally Ovid stresses natural or adoptive relationships in the imperial family far more often than the political meaning with which Augustus had worked hard to imbue these terms.

Imperium, a word infrequent in elegy, is almost as frequent in the exilic poems (17) as in the rest of Ovid's oeuvre together (21, of which 11 are in the Fasti), but only in Phase 1 (6) and Phase 4 (4) does the word relate to Augustus. Varro (Ling. 5.87) derives imperator (notoriously a metrical impossibility in dactylic verse) from imperio populi qui eos, qui id attemptassent, oppressisset hostis ("from the rule of the people that oppressed those enemies that would have tried to oppress it"; my emphasis). Augustus appears by the time of Ovid's exile to have virtually annexed terminology deriving from the word imperium for the exclusive use of himself and his immediate family. ${ }^{25}$ Ovid seems often to be attempting to redirect the domain of this semantic set to a sphere wider than the Caesarian house, back to Varro's populus. Some occurrences, in the fifth phase, are either religious or connected with the various consulships of some of his addressees, with only two exceptions, both in $P 4.13$ (28 and 33), referring to Tiberius' rule. The first of these offers interesting support to Tacitus' depiction of Tiberius' reluctant accession: qui frena rogatus /

23 Irony may be read here. Tiberius was clearly Augustus' last resort, when all other candidates for adoption had fallen away. $P 2.8 .31$ and $P 4.13 .27$, with the poet's bland acceptance of the resemblance between "father" and "son", accentuate by ommission the fact of his adoption. Cf. Ahl 1984.

24 Maltby 1991 s.v. Hereafter, unless otherwise specified, ancient etymological references will be taken from this source.

25 See Syme 1979 on Augustus' appropriation of the title as cognomen, and the discussion by Brunt and Moore (1967:12-14) of Augustus' maius imperium (Introduction to the second reprint [1973] of their edition of Augustus' Res Gestae). 
saepe recusati ceperit imperii ("after he was asked to do so, he took up the reins of that rule that he has so often refused", P4.13.28).

The table shows an increase through the first four stages and then a decline in the relative frequency of other words from the semantic set that relates to imperial rule, pax and hostis. Pax is most common in a negative context, as something the exile has lost, whose non-existence in the Pontic region, a major argument for Ovid's request for recall, implies negation of the pax Augusta. ${ }^{26}$ Its marked decrease in frequency by the last phase indicates rather the inefficacy of this appeal than newly discovered virtue in the local populace. This is borne out by the changing usage of hostis. In Phase 1, five of the first six occurrences are in sententiae, gnomic statements about human behaviour, three refer to the exile's location among "enemies". Only one refers to a personal enemy. The exile appears largely oblivious to personal hostility evinced by any individuals other than the emperor. In Phase 2, nine allusions are to the exile's situation, one a gnomic expression. Phase 3 has three gnomic statements, four allusions to the situation. Phase 4 heightens its appeal with eighteen references to danger from local enemies, four gnomic sayings, and one allusion to the personal enemy of a correspondent ( $P 3.8 .20$ hoste, precor, fiant illa cruenta tuo, "may [the arrows] become [red from the] blood of your enemy").

Hostis as the poet's private "enemy" in Rome occurs only thrice. In $T 2.77$ the word refers to the person who first brought his erotic works to the emperor's attention. The use of the word here casts a dubious light on Augustus, who, by association, is also an "enemy". In T5.1.56 whoever tries to prevent the exile's tears is "durior hoste". In P3.1.152 he attempts to disarm an enemy by awarding the role of hostis to Fortuna alone. The poet's own (unnamed) enemy is never "inimicus". Of four occurrences of this word, three are linked with non in the context of a double negative, the fourth in a "triple negative": vix tunc ipse mihi non inimicus eram ("then I scarcely was not myself an enemy to myself" = "then I really hated myself", T2.82), all therefore creating strong positives. The word seems to lend itself here to circumlocution.

\section{Politics shading off into friendship}

Words prominent within the overlapping semantic fields of politics and private friendship in the exilic oeuvre are: amicitialamicus, officium, meritum, studium, favere, foedus/fides/fidus/fidelis, velle, cupere, amare, deligere.

Hellegouarc'h (1963) lists amicitia as a political concept. In the Roman context it often was. ${ }^{27}$ Catullus exploited this concept by transferring the idea of Lesbia as his amica ("girl friend") to the sphere of amicitia and relating to it concepts such as foedus, fides and obligatio. Although amicitia should have been durable between Roman politicians, as theoretically they shared the same moral and political principles, in practice amicitia sometimes was a mere matter of courtesy, "a way of

26 Some occurrences have a different context, or pun on the expression pace tua.

27 Leach (1993) shows that whether Cicero is articulating an ideal or codifying a system, his $D e$ Amicitia indicates gradations in quality of an acknowledged reciprocity. 
overstepping covert enmity" (Brunt 1965:6). Augustus used the concept freely. Amicus principis became an almost political title. Of Ovid's correspondents, the most famous amicus principis is Fabius Maximus. Loss of Augustan amicitia probably led Fabius, like Cornelius Gallus long before him, to commit suicide. ${ }^{28}$

Amicitia and amicus are very frequent, occurring about ten times as often in the exilic poems as in the rest of the Ovidian oeuvre. Not unsurprizingly, the set triples in frequency in the fourth phase (where friends are personally named, and appeals often are cast in the guise of advice on the duties of friendship), dwindling again in the last.

The poet proposes to his friend Brutus in the prologue to $P 1-3$ that he should replace the offending three books of the Ars Amatoria with this new collection (P1.1.12). So P1-3 becomes an "Ars Amicitiae". Ovidian amicitia is, however, seldom political. It is predominantly private and personal, with amicus frequently in the vocative case. Political undertones are discernible in T2.81, esse sed irato quis te mihi posset amicus? ("Who could stay my friend if you were angry with me?") and T5.9.21, di tibi se tribuant cum Caesare semper amicos ("may the gods, with Caesar, always show themselves as friendly to you"). Yet amor as the relationship between friends is still less frequent than the erotic sense of the word, even in the exilic poems (nine out of 32 in the Tristia and five out of 20 in Ex Ponto). ${ }^{29}$

Ancient sources from Cicero Laelius 26 onwards adequately derived amicitia from amor, but amicus was later fancifully connected with animi aequus (Cassiodorus In Psalm. 37.121.238A), animi custos (Gregorius In Evang. 27.4) and even hamus...catena caritatis ("a hook as a [binding] chain of love", Isidorus Orig. 10.4). Such derivations would not have displeased Ovid, but there is another factor: underlying every solemn reference to Roma there may be lurking reminiscences of the poet's earlier works, where the punning potential of its palinode amor was often exploited, as in Ars Am. 1.55, tot tibi tamque dabit formosas Roma puellas ("so many and such beautiful girls will Rome provide for you"). In the didactic poem it was not amor, but Roma, that supplied the apprentice lover with girls. In the exilic works Ovid appears consciously to reverse any such punning allusions by the straightforward use of both amor and Roma, but, in the context of his earlier works, an echo reverberates in $T 2.321$, nec mihi materiam bellatrix Roma negabat ("and warlike Rome never denied me material"). His readers in Rome would know that, far from his having sung of warlike Rome, it was bellator Amor ("fighting-fit Love") that had formerly been the poet's main theme.

28 Tac. Ann. 1.4. See Rogers 1959 and 1966 on the "emperor's displeasure", also listing the voluntary exile of Silanus, the lover of Julia Minor, who was allowed to return to Rome under Tiberius.

29 The occurrences listed in the Table relate only to the non-erotic use of the word, as referring to the relationship between friends, and which occurs also in connection with Rome (T1.3.49, $T 2.160 ; P 1.3 .29)$, death $(T 1.5 .6 ; T 3.8 .39)$, praise $(T 5.7 .21 ; P 4.7 .40)$ and in other equally neutral contexts. In Ovid's other elegies, (mainly erotic) amor is the third most frequent noun, after puella and ars (Purnelle-Simart and Purnelle 1987, s.v. and n.18 above). 
Pietas and its cognate pius with all their Virgilian undertones are frequent in Ovid, particularly in the Fasti. The words may sometimes require an ironical interpretation as in $T 1.3 .86$, where the exile's wife pleads to be allowed to accompany him as Caesar has driven him, ...pietas haec mihi Caesar erit! ("Duty will be a Caesar to me!"). The word gains in resonance when it is remembered that pietas is another of the salient characteristics Augustus names in Res Gestae 34. Allusions to the imperial family invite an ironical interpretation, as in $P 2.2 .75$, where nurum neptesque pias natosque nepotum ("your daughter-in-law [presumably Antonia, wife of Drusus] and loyal granddaughters and the granddaughters' sons") highlight by omission Livia's (step-) daughter-in-law and granddaughter that had been judged "impiae". The poem is addressed to Messalinus, younger son of that Messala Corvinus who brought the pater patriae proposal before the senate in $2 \mathrm{BC}$, and its whole lends itself to second and less favourable interpretations, in the spirit of what Ahl (1984) terms "the art of safe criticism", e.g. vv.29-31 and vv.99-100 on the dangers of evoking the emperorgod's wrath by seeking sanctuary with him, or even by helping the exile, reference in 42 to Augustus as the "Tarpeian thunderer", which evokes both an implication of arrogation of deity and of primitive, peremptory justice, and, most damningly, 115119 , depiction of Augustus as a kind parens, whose dire punishment of others (by implication his children) hurts himself in equal measure. It is not difficult in the last case to read another allusion to Augustus' harsh treatment of his daughter and granddaughter, which, whether justified or not, caused him much grief.

Fides was considered by the ancients to derive from fit quod dicitur ("what is said, happens", cf. Cic Fam. 16.10.2). From Catullus (Carm. 76.3) onwards, readers would be accustomed to the adaptation of the words fides, (fidelis) and foedus to an erotic context. This set in Ovid occupies six columns in the Concordance of Deferrari et al. (1968), 240 occurrences in all. Their relative distribution in the exilic works somewhat surprizingly contrasts with the distribution of the "friendship" words, being most frequent in the first and last phases, lowest in the second. Ovid most commonly implies a sense of "faithfulness, faithful obligation" in relation to a friend, sometimes in gnomic statements, e.g. T1.5.39 saepe fidem adversis etiam laudant in armis ("Often they even praise loyalty in their adversaries). Foedus (also from root *fid-, recognized as such by Cicero, so Servius on Aen. 8.641) occurs only seven times, once in connection with the exile's relationship to his wife. The Catullan echo is clear: P3.1.73, exigit hoc socialis amor foedusque maritum ("This our shared love demands, this our marriage compact...", transl. Green 1994). The novelty lies in the address of a real wife. Here, as elsewhere (e.g. T1.3 passim, T3.3.15-24) in the way the exiled poet spells out his love for his wife there seems to be an attempt at rewriting his reputation as a lusor amorum. ${ }^{31}$

Frequency figures for the complete set, *amic-, non-erotic amor, pius and pietas and the *fid-words, fluctuate between a low in Phase 2 Two (fewer than 24 per

30 Absolute figures: Am. 10, Ars Am. 9, Met. 53, Her. 23, Fast. 35.

31 Fiducia, "trust", occurs only four times. At T5.2.71 it should be translated as "certainty": pax tamen interdum est, pacis fiducia numquam ("There may be peace at the moment, but the certainty of peace is never guaranteed"). 
1000 verses), to almost 38 per thousand in the fourth phase, thanks there to the high frequency of amicus and amicitia.

Political amicitia involved obligatory duties. An officiosus friend would perform an officium, a service. The words derive from opus facere, to do a job (so Lewis and Short) but for the ancients, with scant distortion, from efficere, to achieve, carry out (Maltby 1991 s.v.). The terms are frequent in Ovid's other works (59 instances, of which 27 in the erotic elegies, 16 each in Met. and Fast.) and in the exilic works they recur with increasing frequency, culminating in what we have called Ovid's Ars Amicitiae (Phase 4: 16 instances). Eleven occurrences in the last phase indicate a continued trust in friendship. In exile the words often relate to the writing of poetry, as in T4.7.4, cur non tua dextera versus / quamlibet in paucos officiosa fuit? ("Why didn't your right hand ever turn to extending me even the slightest form of friendly duty?"), and P1.1.20, Musaque ad invitos officiosa venit ("My Muse comes to offer friendly aid even to the unwilling"). Nagle (1980:71-82) stresses the semantically related utilitas, (which implies efficacy), especially of poetry. Utilitas occurs nine times in the exilic corpus, often in a negative context, as T4.1.38, sed quiddam furor hic utilitatis habet ("even this madness has some use"), or P2.3.8, vulgus amicitias utilitate probat ("the common herd tests friendship by its usefulness"), P4.12.46, nec satis utilitas est mea nota mihi ("I don't really know well enough what is good for me").

Studium in Lewis and Short has as basic meaning "a busying one's self about or application to a thing". In the context of political amicitia it is used for "interest in", as in P2.5.60, et servat studii foedera quisque sui ("and each man honours the pacts / that are proper to his particular calling", transl. Green 1994). In the exilic works its political connotation is secondary and the word refers predominantly to "studies", "scholarship" as in $T 2.9$, deme mihi studium... ("take away my studies...") or T5.12.51, si demens studium fatale retemptem (...if I should, like a madman, take up this fatal study again"). ${ }^{32}$ In either sense, it is most frequent in Phase 4 (15 occurrences). Favere and favor together display a similar distribution pattern, with 16 occurrences in the fourth phase. With Ovid the semantic field of the highly frequent root ${ }^{*} f a v$ - in the context of amicitia usually involves condescension from a greater to a lesser personage. A possible exception is T1.2.101 domui si favimus illi where the active agent is the exile, pleading on the ground of past merit, "favour to the house of the emperor". ${ }^{33}$ The complete set ("g" in the table) is relatively far more frequent in the exilic works than in the rest of Ovid's corpus (118 examples here, representing $43 \%$ of all occurrences of these words). Colere as a political act is relatively infrequent in the exilic poetry: of about 40 instances throughout, its political or social meaning predominates in phases two and five, but the word in general is restricted to its religious domain, including cultivation of his Muse by the poet as vates. Its cognate cultor is almost exclusively religious.

32 This is the traditional intellectual refuge of an exile, featuring frequently in the consolatory tradition as a means of solace (cf. Claassen 1989:266).

33 The poet may be implying his own greater worth, but this should not be overstressed, as a similar usage in P4.14.56, publicus... favor has no discernible ironic undertones. 


\section{Legal vocabulary}

The condemned exile predictably resorts to legal vocabulary in his appeals to his judge. The words under consideration that comprise a single semantic set, are arguere, fateor, poena, crimen, culpa, error, exsul, relegatus. ${ }^{34}$ Of these, some do not reflect the pains of exile. Although forming part of Nagle's list (1980:67-68), and attested to in Pichon (1902) these words do not spring to mind as essentially erotic. Where the poet has formerly employed them as such, here they are apparently consciously restored to their original provenance, thereby perhaps also offering the exile a way of "sanitizing" their earlier erotic use. Some appear merely neutral.

Fateor, "I confess", is frequent, but often in parentheses, as a verse filler, seldom in a legal connotation. The exile confesses to "fearing", to having "lied", to having done "nothing more than make a mistake", to "not having feared", but never to a crime. Apparently the exile's sense of contrition, or the poet's need for verse fillers, fluctuated considerably. The word is relatively most frequent in the first and last phases, least frequent in the second. The nearest to a confession of guilt is P2.2.19, esse quidem fateor meritam post Caesaris iram ("I confess that Caesar's anger is well-earned"). Again, as ever, the guilt is left unspecified. ${ }^{35}$

Arguor, "I am accused", the semantic complement of fateri, first occurs in $T 2$, Ovid's "speech for the defense" (212, arguor obsceni doctor adulterii and 327, arguor inmerito!). Other occurrences of the word are unrelated to accusations against the exile. The substantive common with arguo, crimen, has a wavering semantic field: from "accusation" to what in English is termed "crime". It is a common Ovidian word: its 55 occurrences in the exilic works represent only $26 \%$ of total occurrences. Both senses feature here, most often in denials of guilt: the word is most frequent in the first phase, which includes $T 2$ (23 occurrences, or 1,8 per hundred verses). The second phase has 17 occurrences, and the other three phases together only 17. Paranomastic play on carmen-crimen is first coined at 12.207 : perdiderunt me duo crimina, carmen et error ("I was ruined on two counts, my song and a mistake") firmly connecting Ovid's poetry with his "crime". Once established, this relationship echoes throughout, and can' be evoked at each of the subsequent 134 repetitions of the word carmen/carmina. ${ }^{36}$ At the last, P4.14.42, the relationship is firmly restated: inque novum crimen carmina nostra vocat ("and my song calls me to a new transgression"). ${ }^{37}$ Here the first meaning suggested above is involved. The

34 Recourse was had for this part of the discussion to Tracey 1978-1979 and Focardi 1975. Deratini's (1916) list of rhetorical and didactic vocabulary in the erotic poems overlaps with Ovid's exilic vocabulary, but the words do not merit special discussion, being the Latin equivalents of common Greek oratorical terminology: turpe, pudet, decet, conveniens, utilis, tutum, nocens, meritus, tempus, nox, dies, caelum, aethera, adde quod, adice, finge, vidi, i nunc, quid referam/narrem, cura, mors, etc.

35 Historicists are no nearer solving the "mystery" after the works of Thibault (1964) and Verdière (1992).

36 Distribution of carmen is $40,24,18,34,33$. Relative frequency is highest in the first and last phases, lowest in second and fourth.

37 Maltby's (1991) large collection of ancient sources on carmen and crimen indicate fanciful 
exile needs to defend himself against a new accusation: his poetic complaints about the harshness of his place of exile have incensed the local populace and he is now obliged to deflect their ire with praise for their kindly amelioration of his outcast state (43-56). More of this below.

The word is part of a semantic set referring to "guilt". With Ovid three degrees or shades of culpability are reflected ("crime": crimen/adikêma; "fault": culpa/hamartia; "mistake": error/atychêma). Of these he admits to only the least serious, error ("a mistake"), and rejects all culpa ("blame, fault"). Lewis and Short relate error to the IE root *er-, "to wander" (as did Varro Ling. 6.96). Culpa is related to Skr. *skhal- "to fall". It may be virtually equated with errare, from which may be derived the further sense of "a state worthy of punishment arising from a wrong judgement", which is all Ovid will ever admit to. Of importance is what we can deduce from Ovid's use of the two words about his attitude to his punishable deed. Comparison of frequency indicates a significant shift of emphasis. The frequency of culpa reaches a climax in the fourth phase, with 14 occurrences in the series 8, 6, 7, 14,2 . Figures of relative frequency give a clearer picture: error is relatively most frequent in Phase 2, disappears in Phase 3, and is infrequent in Phase $4 .{ }^{38} \mathrm{Culpa}$ is most frequent in the third phase, but drops to the same low frequency as error in Phase 4, with further diminution in the last phase. Only once culpa is tempered by the adjective imprudens (T2.104). The exile appears ready to admit to some blame in the first years of exile but by the fourth phase he only once admits to a "fault" ( $P 1.1 .64$, culpa perennis erit). It is clear that the exile is changing his tack: no amount of selfinculpation will move his imperial reader, and he drops the ploy. In the last phase blamelessness is twice attested: at P4.6.15 in the context of the death of his patron Fabius Maximus, when Augustus "had begun to forgive his fault", and, finally, nulla est mea culpa (P4.14.23) - but this is in exculpation of the accusation of ingratitude brought against him by the Tomitans, referred to above. ${ }^{39}$ From first to last, the exile will not accept any serious culpability for his past or present.

While making the most of the pathos of exile, and stressing his longing for his native soil, if only to be buried in it (T3.3.70), the poet twice (in Phases 1 and 3) distinguishes between "exile" and "relegation". Ovid was not exiled, merely relegated ("sent away"), which meant he retained his possessions. A Roman citizen would, however, lose his citizenship if he settled permanently in another locality, so, although he was technically not exiled by imperial decree, Ovid's permanent relegation implied loss of civic rights, and he frequently stresses his diminished status. Exul was commonly written exsul, for, on the evidence of pseudo-Quintilian, Caper and Scaurus, ${ }^{40}$ the word was considered to relate to solum (probably "ex

etymology that relates both words (with Camenae) to various roots containing the combinations ${ }^{*}$ car-/*cas-. Common derivation from carere in a late source (Isid. Orig.) acknowledges the traditional link: a crime lacks a "name" (5.26.1) and a singer-poet lacks a "mind" (1.39.4).

38 Not all occurrences of error relate to the poet's misdeed.

39 "Guilt" implies an angry opponent, who may also forgive. The words ira, mitis, lenis are discussed below in the context of Augustus as god.

40 Ps.-Quint. Decl. 366.400.13; Cap. Gramm. 7.22.14.95.16. 
solo"- "from the soil"). ${ }^{41}$ This etymologizing appears to have been derived from the fact that in Roman law change of domicile was known as solum vertere ("changing soil"; cf. the English phrase "on native soil"). Loss of civic status was immediate only in cases of solum vertere exilii causa ("changing place by reason [of being] exile[d]"), involving escape from capital condemnation or if the sentence imposed was interdictio aquae et igni ("interdiction from water and fire"). Of ten occurrences of the word solum in the exilic oeuvre, eight appear to refer either positively to the poet's fatherland, or negatively to his place of relegation, of which the most specific is his prayer that the Sarmatian soil should not cover his bones, P1.2.60, and one, $P 2.2 .68$, specifically requests a "change of soil". 42

Contrary to what might have been expected, the semantic set exsul and its cognate verb exsulare (with exsilium and relegare) ${ }^{43}$ are relatively sparse. The words virtually disappear toward the end, after fairly consistent use (once in about every hundred verses) throughout the first four phases. In the last phase the strictly legal aspect of being a relegatus is touched on twice, but allusions to exile hardly feature. One may argue that the exile has resigned himself to his lot, but it may also be that he has realised the inefficacy of this particular pathetic ploy in appeals to the imperial family and to his friends.

\section{Religious vocabulary}

The languages of religion and politics frequently overlap in Roman poetry: pietas as discussed above has some religious undertones. For Ovid, writing poetry is a divine calling, and he sees himself as a member of a divinely-inspired fraternity. Hellegouarc'h (1963) ascribes sodalis (with sodalicium, sodalitas) to a politicoreligious context. The word is cognate with Skr. svadha, "will, power" (so Lewis and Short), but its origin was ascribed by the ancients to the act of "sitting down to a common meal" (from sedere, so Festus Gloss. Lat. 297 etc.). In Ovid it often appears as synonymous with amicus, but its religious undertones cannot be ignored, and the implications of its contemporary etymology are exploited in the poet's celebration of his sodales as his boon companions. But they are also his fellow-poets and fellowworshippers of the Muse.

Consequently, the poet sees himself as vates, singer of divine truth, a designation that increases with time. ${ }^{44}$ From a rather impersonal use once in the first phase, the poet progresses to five allusions to "poets as vates" in the second phase (T4.10.42 equates vatic poets with "gods"), to designating himself as vates four times in Phase 3. The word does not feature in the first book of Phase 4, but thereafter the poet increasingly ascribes the term to himself. Three of eight occurrences in Phase 4 refer directly to himself, as e.g. P2.9.65, ad vatem vates orantia bracchia tendo ("as

41 Lewis and Short postulate a derivation of exul / exsul from the root "sal-, "to go".

42 The exception, $P 2.11 .28$, alludes to the birthplace of a correspondent.

43 This semantic set does not occur in the erotic poems; there are five occurrences in the Heroides, ten in the Fasti, and, perhaps surprizingly, only thirteen in the Metamorphoses.

44 Vates occurs in all but the third phase. Newman (1967) denies any profound understanding of the concept of vates in Ovid, against whom see Claassen 1986 passim. 
Apart from this outrageous passage, where use of the word should be taken as a single occurrence, a triple designation of Germanicus as the plural numina in the course of $P 4.8$ can also be taken as essentially a single reference. The word is decreasingly applied to the imperial family, its use in the imperial context dwindling noticeably from first to last, either a sign of final discouragement in the exile about the usefulness of such a ploy, or a further indication of a change in the poet's interests and choice of topics.

A more sinister equation is reflected in the substitution of the terms fatum and fortuna (roughly equivalent to the Greek Moira) for "Caesar", often with a strongly negative connotation. Fatum (from root * $f a$-, "to utter, appear", so recognized by Varro Ling. 6.52) has many related shifts of meaning, from "fixed lot, what has been spoken or decreed" (even as an equivalent of vita "life"), to passive "what will happen" or "has happened", to "instrument of doom", to "death" (as an equivalent of mors). Its plural fata, "fates" or Parcae combined the ancient Greek idea of "the rulers over the thread of life" with "verbal prophecy", "what has been decreed". 54 fatalis as adjective takes on related meanings. Often fata in the plural, as active agent, virtually equals the emperor, as in 73.6 .15 , sed mea me in poenam nimirum fata trahebant ("but my Fate doubtless dragged me toward punishment") and P4.9.36, mitia ius urbis si modo fata darent ("if only a milder Fate would vouchsafe me [the benefit of] civil law"). In both cases the exile's lot and the person who decreed it appear interchangeable, and covert criticism of the powerful imperial personage may be read into these words. The poet was exiled because the emperor spoke the decree, not because he had in any way transgressed.

Fortuna, "chance" (from fero, "to bring", but related by the ancients merely to its cognate forte ${ }^{55}$ ) is in Roman thought most often the incalculable factor bringing victory or defeat (the Greek tychê), but often is used, as in English today, as the equivalent of "possessions", "what has been brought by chance". 56 Kajanto (1961) sees Fata as a Homeric concept, Fortuna as Hellenistic. In the exilic works the concepts merge, being both the "agents shaping events", and the "outcome of these events". Here too, Augustus as an agent "shaping events" appears as their shadowy equivalent. ${ }^{57}$ Sors (from sero, "sow", Lewis and Short, but so too Varro Ling. 6.65) "a lot, throw of chance" usually implied the "impersonal decision of fate". For Ovid it most frequently implies "lot in life", the result of the decrees of fate (or of the emperor), as when he rebuts a suggestion that he should console himself with the

54 Parcae is related to "plek-, "fold", so Lewis and Short, but to Ovid's predecessors from Varro, ap. Gellius 3.16.10 onwards, it derived from parior, "give birth", with probable reference to the belief that a child's fate was decreed at birth by the three dire sisters.

55 August. De civ. D. 4.18 and Isid. Orig. 8.9 .94 etc.; Maltby 1991 s.v.

56 Deferrari et al. (1969 s.v.) differentiate between the two usages by use of lower and upper case letters. The word occurs 75 times in the exilic works, against only 40 occurrences in Ovid's other works.

57 See Kajanto 1961; I have not seen Birnbaum 1970 on the equation Augustus=fortuna. 
usual occupations of an exile, namely study: he cannot, he says, for sorte nec ulla ulla mea tristior esse potest (T5.13.6). ${ }^{58}$

The combined semantic set fortuna, fata, fatalis, Parcae, (dirae) sorores and sors is typical of Ovid throughout his oeuvre (539 instances, of which $27 \%$ in the exilic works). The set has its highest frequency in the third phase where the exile often complains about the hardness and inevitability of his lot, as in the example cited above.

The synonyms mitis and lenis, "kind", words elsewhere often associated with divinity, ${ }^{59}$ are here frequently applied to words denoting the emperor, with almost formulaic regularity. Thence fata can plausibly be equated with "Augustus" in mitia...fata (P4.9.36) quoted above. Mitis occasionally applies to the exile's wife and friends, but more often to the emperor, in combination with requests for a better place of exile. ${ }^{60}$ Mitis and lenis sometimes combine paradoxically with ira, a typically divine attribute. Its root is cognate to the Greek eris "strife" (with the implication of the involvement of both protagonist and antagonist), but ancient etymologists associated it with "departing, taking leave (of oneself)", implying unilateral action by the antagonist, so Donatus on Ter. Phorm. 794. With Ovid this subjective implication predominates, and the word means "wrath", but often the implication is that the poet's antagonist has exceeded just bounds, a concept that accords with the ancient etymology of the word. The exile felt the ira of the god, of Caesar, of the princeps, of the numen and of "that man". Use of ira (with its cognates iratus and irascor) decreases from phases one to three, again perhaps an indication that the exile was turning his attention elsewhere. Yet Phase 4 shows a marked increase, deriving from the exile's increased outreach to potential mediators between him and the being he has angered. During the last phase significantly less concern about the emperor's anger may be ascribed to the death of Augustus in $14 \mathrm{AD}$.

Prayers for remittance of sentence are expressed by means of the verbs precor and oro and the less frequent noun preces. Oro is predictably less frequent, deriving as it does from os "mouth". One of the exile's chief complaints was that exile offered him no chance for personal communication. He could write to Rome, but there was no-one to speak to. The words involving the root *prec- (cognate to Skr. ${ }^{*}$ pracch/*prast-, Ger. fragen, Eng. "pray"), "to ask" (but not necessarily of a divinity), predominate. The combined statistics for precor and oro show a strong appeal during the first two phases, which virtually ceases in the third phase, arising anew in the fourth phase when friends are addressed on the subject of amicitia and its obligations.

58 That the very rebuttal is an example of such an exercise shows the poet's old sense of fun still at work.

59 Lewis and Short are dubious about the etymology of mitis, comparing it with Skt. *mith-, "to associate". Only the late authority Isidorus (Orig. 10.168) attempted derivation, associating it with mutus, "uncomplaining", and, by opposites, with Manes, as "inmites" (id. 1.37.24). Augustine Dialect. 6.10 correctly identified (via limus, $-a,-u m$ "askance") a relationship between the root *li- (Gk. leiô), "make smooth" and lenis, "soft, pliant".

60 Of seven occurrences of mitis in Phase 5, four refer to the emperor (e.g. P4.5.32, a miti Caesare) and three to friends (e.g. P4.15.32, ...mitis anice...). 
The exile's appeals, beside supplication of the purportedly divine imperial family, predictably reach out into the sphere of private and political friendship. Again the words are not specifically "elegiac" or "erotic", but may be said to have reverted to their original provenance.

\section{The specialized vocabulary of exile}

Now to the specialized vocabulary of exile, comprising words for longing and desolation (largely pathological and psychological terms-these may be seen as continuing the "elegiac" mode), the language of poetics (embracing more than the carmen mentioned above) and a vocabulary of defiance and endurance. ${ }^{61}$ Ovid's vocabulary of pathos derives largely from precedents set in the Heroides. ${ }^{62}$ The most important are queror, querulus, fleo, flebilis, lacrima, litura, miser, vereor, timor, metus, stupor, torpor, attonitus, solus, sollicitus, tristis, infelix, pudet, procul, longe, extremus, ultimus, abesse and deesse, desero, desiderium, diversus, peregrinus, profugus, vulnus, cura, morbo. Many of these, although not intrinsically "erotic", also occur in amorous elegy, especially in the context of exclusion from the beloved, and are therefore reflected in Pichon's list.

Ovid's heroines were frequently "tearful"; the exile more often exhibits other signs of a growing unhappiness. In the Heroides, the words queror/querulus, fleo/flebilis/fletus, lacrima, litura, plango(r) occur 170 times, of which lacrima (51) and *quer- (39) are most frequent, as against 62 occurrences of the whole set in the exilic works, where plangor does not feature at all. The pattern of occurrence of lacrima, fleo, flebilis and fletus together, through the stages of exile, is erratic: 10, 18, 8, 23, 4. Some occurrences are retrospective in context: some poems from Phase 2 recall the exile's departure (which belongs in the first phase), and in Phase 4 the exile weeps for lost friends. Other words in this set increase in frequency from first to last, indicating no remission of misery.

The semantic set attonitus, infelix, miser, sollicitus, tristis, pudet (all reflections of the subject's inner life) is represented by 85 occurrences in the Heroides, by 158 in the exilic oeuvre. Their distribution here is suggestive. By Phase 4 the exile has, perhaps not surprizingly, ceased to be attonitus ("lightning struck with unpleasant surprise") or sollicitus ("worried") but he continues unhappy, miser (69 occurrences in all). Tristis is most frequent in the second and fourth phases. The second century Festus (351) derived sollicitus from solo citare... "[i.e] ex suo loco ac sententia...". This zeugmatic derivation is most apposite to the circumstances of an exiled poet, as pointed out in the context of exsul (solum vertere exili causa) above. About miser Isidorus Orig. 10.173 quotes Cicero Tusc. 1.9 on the dead as "miseros...propter quod iam amiserunt vitam". Such a fanciful etymology could have

61 Recourse was had for this part of the discussion to Lueneberg 1901; Deratini 1916; Buescu 19581959; D'Elia 1958-1959; Baca 1971; Viarre 1974; Dragulescu 1976; Hellegouarc'h 1976; Oton 1976; Doblhofer 1978 and 1980; Soraci 1980; and Osmun 1983. Cf. Claassen 1989. 
represented reality for the exile, who frequently depicts removal from Rome as "living death", loss of all life that he held dear (Claassen 1996).

Malus and mala (the latter as substantive for "ills") are emotionally related to the above semantic set, in that the words reflect the exile's inner perception of outer reality. Their relative frequency displays a decreasing arc. ${ }^{63}$ The poet appears over time to be moving away from depiction of outer ills to concentrate more strongly on his inner life.

The semantic set comprising words of destitution or desolation is represented by 72 occurrences in the Heroides, 143 in the Tristia and Epistolae ex Ponto. The words are: desero, desiderium, diversus, extremus, ultimus, procul, longe, peregrinus, profugus. Perhaps surprisingly, the fourth phase does not display a proportionate increase of expressions denoting "longing" as the exile attempts to gain sympathy from his friends. More prominent are words denoting "distance": procul (9) ultimus plus extremus (11), profugus (6), longe (5). With Ovid ultimus sometimes has a temporal connotation, "last in time" as in the "last deed of his life that brought about his downfall": T2.99, ultima me perdunt ("the last ruined me") and his "last (third) wife" and T4.10.73, ultima...sustinuit coniunx exulis esse viri ("the last experienced being the wife of an exile"), but generally the focus is on vast spatial distance between the exile and home. Ten out of fourteen words of desolation in the last phase come from this subset; the others are all derived from desero (all but one applied to the exile). This word and its cognate deserta relate to sero "to join", implying disjunction, but were by the ancients derived as antonyms from its homonym, which means "to sow" (Isidorus Orig. 14.8.31 etc.). Ovid makes much of the bareness of his place of exile and its lack of agriculture (e.g. T3.12.13). The paranomastic possibilities of like-sounding desiderium (of uncertain etymology, so Lewis and Short) could have prompted continued frequent use of the word in the exilic poems, as elsewhere in the Ovidian oeuvre, which often deals with loss and longing. ${ }^{64}$ Ancient etymologists ascribed the origin of the word to "a change of stars" " $d e+$ sidera", Paulus Diaconus Epit. Festi 75), which again, in the context of Ovid's exile, opens interesting possibilities. He consistently depicts himself as living "under a distant star", even "the Polar star" (T1.5.61, T3.4b.1, T4.4.62, P4.10.40).

An important part of Ovid's very specialized exilic vocabulary deals with his inner resilience. Here one word with a widely divergent semantic field and widely differing emotional appeal stands out: the imago, the surrogate vision, a unique exilic concept. It has a fluctuating semantic field, depending on the presence or absence of symbolism or degree of abstraction. In the Platonic view an idealized concept is more "real" than a transitory object. In that sense an imago, a mental vision, can be more "real" than the concrete object it represents. A reflection in a mirror is also an imago, transitory in a different way; so too a picture on a wall, a concrete representation of either another concrete object, or of a concept, a creation of the imagination. ${ }^{65}$ Paulus

\footnotetext{
$\begin{array}{llllll}63 & 1,25 & 2,59 & 2,12 & 1,45 & 0,96\end{array} \rightarrow$ see Table.

64 Figures for this set are exceeded throughout Ovid's works virtually only by the "divine set" (" $l$ " in the table) and the other sets denoting grief, discussed above.

65 Cf. Wheeler 1995 on Ovidian ecphrasis in the context of the imago mundi as a verbal portrayal
} 
Diaconus, following Festus, proposed the derivation of imago from imitatio. This is semantically close to its origin as a cognate of aemulatio, from root ${ }^{*} \mathrm{im}$ - (so Lewis and Short). This appears to have been the significance the word held for Ovid, for whom its basic import was "representation of reality". Context helps the reader to distinguish between the meanings of imago in T1.3.1, cum subit illius tristissima noctis imago ("when a very sad picture of that night occurs to me") the exile's memory of his last night in Rome, and (about the son of Messallinus); T4.4.3, cuius inest animo patrii candoris imago... ("in whose mind is a reflection of his father's brilliance", cf. Viarre 1974). To the poet his poems are, almost in the Platonic sense, a truer representation of himself (maior imago) than his own person can be (T1.7.1112).

The frequency of occurrences of imago is of interest here: in Phases 1 to 4 , the absolute frequency is $4,3,2,8$. In the last phase, imago does not occur, but its place has been taken by the semantically related oculi mentis, "the mind's eye". The concept first appears in the second phase, at T4.1.57, haec ego summotus, qua possum, mente videbo ("These things I, so far removed, see in my mind, [which is the only means] whereby I can"). The future videbo (with absens / animo / mente) gains a similar meaning in the context of the exile's inner life. The impression is not so much of an increase in visionary activity, as of the poet's development of a novel way of expressing such activity. ${ }^{66}$

Mens occurs more frequently in the context of expression of the exile's emotional anguish. Such use of the word implies remembrance of a happier past. Isidorus Orig. 11.1.12 offers (as second variant origin) for mens an etymological link to words for "memory", and gives a list of 25 postulated cognates, some of which appear only faintly to adumbrate a reminiscence of the root *men- ("thought"). 67 These together would serve very well to bolster Ahl's (1986) arguments about the ancients' serious approach to wide-ranging paranomastic play. For the study at hand, Ovid's opposition of mental activity to corporeal suffering is significant. Frequent references to the exile's anguish picture a sensitive thinker for whom Platonic reality is paramount, corporeal reality almost negligible (only eleven references in all to his own body). ${ }^{68}$ This contrasts with the physically sensual approach of the erotic oeuvre and the central position of bodily change in the Metamorphoses. The poet's frequent use of ingenium ("inborn talent", so Varro, Ling. 8.15, Cic. Fin. 5.36 etc.) attests to this same attitude. Many of Ovid's references to ingenium are either negative (he has lost it) or unfavourable (it harmed him), but the combined relative frequency of ingenium and mens (on average once every fifty verses throughout) compared with corpus as applied to the exile himself (relatively scarce in the first phases, dwindling

of the world as fixed backdrop or foil for descriptions of change. I have not seen Dant 1975.

66 Only six instances are attested elsewhere, five in Met., one in $\mathrm{Her}$.

67 Of the most fanciful are: alimentum, argumentatio, carmen, commentarius, lacrima, maestus, vehementia.

6853 further instances of *corp- in the exilic works have a different context. In the rest of Ovid's oeuvre corpus, in all semantic contexts, is extremely frequent, 412 instances in all (as opposed to 220 for mens and ingenium). 
further toward the last) underscores the superiority in the mind of the poet of the exile's mental activities and woes over matters corporeal or physical. The exile's unhappiness has been depicted differently from phase to phase, with decreasing concern about "distance from home". The final impression is predominantly of resignation, fewer desires, and more pain. The exile relies increasingly upon the powers of his mind and his poet's imagination.

The poet's "Muse" features prominently throughout the exilic oeuvre, sometimes in the sense of "patron deity", but more often as a synonym for carmen, referring to his poetry. ${ }^{69}$ His Muse is twice designated antistes, solacium thrice. The Pierides, the daughters of Pieros (with variants Pieridas and Pieriae deae), feature in fourteen instances as synonyms for the Muses. ${ }^{70}$ The poet's attitude to his Muse fluctuates from strongly negative to wholly positive. It is important to weigh negative references against positive. The most negative allusion occurs at P4.2.45, quid nisi Pierides, solacia frigida, restant? ("What, beside the Muses, a frigid comfort, remains?"). Yet cold comfort is comfort still. After the second phase, where positive references (5) outweigh negative (3), negatives cease. Positive allusions continue, reaching a vindicatory climax in the very last poem: P4.16.45, dicere si fas est, claro mea nomine Musa /...erat ("If I may say so, my Muse had a great name"). The final judgement of the vates about his goddess is positive, underlining the exile's increasing reliance on his own poetic powers as a source of comfort and support. His confidence in his prowess as a poet is restored, and even overtures to a new imperial patron, Germanicus, are couched in terms of virtual equality; the poet's tone in $P 4.8 .66$, an appeal to the prince through Suillius, although pessimistic, is one of "We poets, my dear Germanicus,...".

The best-known word of defiance in the whole of the Ovidian oeuvre is livor, which editors obligingly grace with an upper case "l" when they suspect personification. Of seventeen occurrences in the complete Ovidian corpus Deferrari et al. (1969) print seven thus, presumably following the editions they consulted for the work. The other occurrences of livor are clearly impersonal. The most violent outburst against personified "Envy" occurs at Rem 389: rumpere, Livor edax! ("Go burst, mordant Envy!"). At T4.10.123 defiance is equally strong:

69 I have dealt elsewhere (Claassen 1989) more extensively with Ovid's ambivalent attitude to his poetry: he both blames it for his exile and relies on it in his defiance of or resistance to fate. The concepts carmen, error, culpa, exsul and relegatus form part of the particulars of Ovidian exile, as discussed, but fade out in first-person exilic works after Ovid (the poems ascribed to Seneca, the Stoic Dio Chrysostymus' narrative of his own exile, Or. 13, Boethius' Consolatio philosophiae).

70 In Met. $5.302 \mathrm{ff}$ the daughters of Pieros are rivals of the Muses, elsewhere (Am. 1.1.6, Ars Am. 3.548, Fast. 2.269 etc.) they are synonymous with "Muses", often no more than an ornamental poetic flourish. At T3.7.4, Pieridas...suas is a metaphor for "studies". 
nec, qui detractat praesentia, Livor iniquo ullum de nostris dente momordit opus.

Nor has Envy, belittler of all that's present, sunk her malignant fangs into any work of mine

(trans. Green 1994)

Address of a personified Envy has its antecedents in the Callimachean tradition of recusatio, and is related by some to the (perhaps dubious) "Battle of the Books", an early literary enmity postulated between Callimachos and Apollonius Rhodios, now largely discounted. Stoessl (1970:265) argues that personified Envy here is a metrical or paranomastic euphemism for Caesar or Livia ${ }^{71}$ Multiple levels of meaning are so often discernible with Ovid, that this possibility cannot be rejected out of hand as "potentially dangerous and therefore outrageous". Such an unnuanced interpretation is highlighted as essentially modern by Ahl (1984), quoting Quint. Inst. 9.2.67. The ancients would have delighted in delicately disguised criticism, and the "tyrant", although offended, could not react to it, as long as an innocent meaning could also be attached to the author's words.

The exile's final address to Livor smacks of pathetic desperation: P4.16.47, ergo summotum patria proscindere, Livor, desine ("So, Malice, sheathe your bloody claws, spare this poor exile.."; trans. Green 1994). ${ }^{72}$ The poet goes on the depict himself as defunct, yet alive to the pain inflicted by his imperial persecutors, as depersonalized in the mysterious ${ }^{*} L i v$. The exile has suffered much at the hands of the imperial family. So the last poem of the oeuvre ends on a sombre note, but the exile's vindication of his place among living poets (vv.3-44) leaves the reader with an impression of the transcendence of mental achievement over matters corporeal, and the creative and visionary power of the mind to transcend time and space.

Conclusions about the exile's attitude to Augustus, and his appreciation of the emperor's iustitia and clementia cannot be drawn absolutely by reference to series of figures. The degree of irony versus surface credibility ("sincerity") needs to be gauged in connection with each reference. Yet from a tentative interpretation of the trend of the figures in the table we may conclude that at first the exile was more defiant, less prepared to concede that he was to blame, less concerned for clemency than for justice, but that this attitude changed in time. At the last a general movement away from both protestations of innocence and cries for mercy leads to an increasing claim on the emotional support of his friends, and insistence on the reciprocity of obligation, culminating in the prolific fourth phase, which offers a surrogate for the Ars Amatoria, an Ars Amicitiae. The drastic diminution of terms relating to imperial matters in the fifth phase points to a final renunciation of externals in favour of the inner life, fed by literary contact with distant friends. Admittedly the thrust of his

71 The empress' name occurs altogether eight times in the whole of Ovid's oeuvre: twice each in the Fasti and Tristia, four time in Ex Ponto. By the end of his life Ovid was perhaps recklessly discarding the circumspection displayed by most of his contemporaries.

72 As substantive: $T 2.455 ; P 3.1 .65 ; P 3.3 .101 ; P 3.4 .74$; personification: $T 4.10 .123$ and $P 4.16 .47$. 
appeal at this stage is directed, through this literary coterie, at a potential new imperial patron, Germanicus, but there are few signs of success. In the end only his Muse offers the exile any solace.

In sum: Ovid has done both more and less than Nagle claims in her designation of his exilic vocabulary as essentially "erotic". He has sent these words in new directions, yes, but these directions tend towards home; he has rewritten their context, thereby clothing his earlier use of the words in a new innocence. He has further established a language of imperial criticism and of poetic vindication which could not be faulted by his antagonist, but which could be read at different levels by a readership sensitive to contemporary meanings attached to these words.

\section{ADDENDUM}

Absolute and relative frequency of specialised vocabulary.

Note: "Relative" represents number of occurrences per 100 verses.

$\begin{array}{lllll}\text { Phase } & \text { Phase } & \text { Phase } & \text { Phase } & \text { Phase } \\ 1 & 2 & 3 & 4 & 5\end{array}$

Books

$\mathrm{T} 1, \mathrm{~T} 2 \quad \mathrm{~T} 3, \mathrm{~T} 4 \quad \mathrm{~T} 5$

P1,

Total verses

1280

$$
1466
$$

800

2264

930

a

clementia
iustitia, iustus
moderor

1

2

Total: Absolute 4

Relative

0,31

$\begin{array}{ll}4 & 1 \\ - & 1 \\ 1 & 1\end{array}$

3

8

\section{5}

0,34

3

$$
3
$$

0,37

14

b pater patriae parens

2

2

$\begin{array}{ll}1 & -\end{array}$

\section{2}

12

Total: Absolute

4

2

Relative

0,31

0,14

3

0,13

2

c imperium

triumphus

pax

hostis

6
-
1
5

Total:

Absolute
Relative

12 0,93

5
2
10

\section{5}




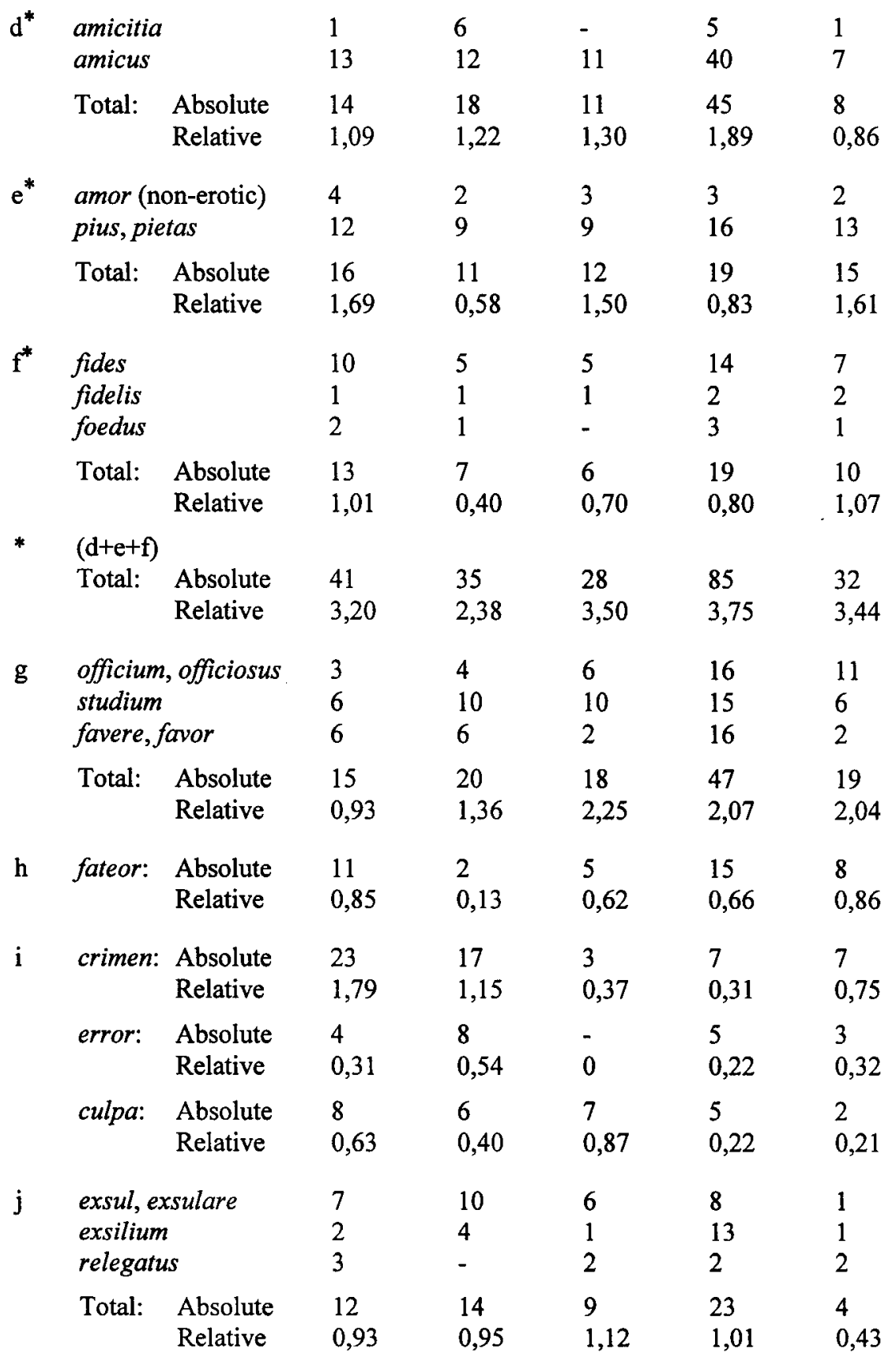


$\mathrm{k} \quad$ sodalis

vates

6
5

$-$

$\begin{array}{ll}5 & 2 \\ 8 & 6\end{array}$

Total: Absolute 4

11

Relative $\quad 0,31$

0,75

4

13

8

Relative 0,31

24

18

0,57

0,86

1 carmen Absolute 40

Relative frequency relating to his earlier works

$\begin{array}{lccccc}\text { Rel. neg. } & 4,7 & 2,7 & 3,7 & 2,6 & 3,2 \\ \text { Rel. pos. } & 3,9 & 2,7 & 2,7 & 1,3 & 1,1\end{array}$

Relative frequency relating to the present (exilic poetry)

$\begin{array}{llllll}\text { Rel. neg. } & 2,3 & 2,0 & 2,5 & 1,6 & 3,2 \\ \text { Rel. pos. } & 0 & 2,0 & 5,0 & 2,2 & 7,0\end{array}$

Musa Abs.neg. $4 \quad 3$

Abs. pos. $3 \quad 5$

$0 \quad 0$

$0 \quad 0$

$\begin{array}{llll}5 & 4 & 8 & 7\end{array}$

Total:

$\begin{array}{llllll}\text { Absolute } & 47 & 32 & 22 & 42 & 40 \\ \text { Relative } & 3,67 & 2,18 & 2,75 & 1,85 & 4,30\end{array}$

m deus: Absolute 33

(Relative) $\quad 25$

$25 \quad 21$

57

$(2,62) \quad(2,51) \quad(2,04)$

Jupiter (Jov-)

12

$(1,70)$

2

9

divus

1

10

numen

15

3

Total: Absolute 71

Relative $\quad 5,54$

43

2,93

$-$

6

1

2

29

28

$-$

9

$\mathrm{n}$

fortuna
fatum/fata
fatalis
Parcae
sorores
sors

$\begin{array}{ll}9 & 17 \\ 4 & - \\ 1 & - \\ - & -\end{array}$

$\begin{array}{ll}13 & 11 \\ 17 & 9 \\ - & 3 \\ - & 2 \\ - & 2 \\ 4 & 2\end{array}$

$95 \quad 30$

Total: Absolute

Relative

34

29

$4,19 \quad 3,22$

o mitis

mitis
lenis

7

7

5

2

5

3

13

6

Total:

$\begin{array}{ll}\text { Absolute } & 9 \\ \text { Relative } & 0,70\end{array}$

7
0,47

8

16

$16 \quad 6$

$$
1
$$$$
1
$$

$\begin{array}{ll}1 & 1\end{array}$




\begin{tabular}{|c|c|c|c|c|c|c|c|}
\hline \multirow{5}{*}{ p } & \multirow{2}{*}{\multicolumn{2}{|c|}{$\begin{array}{l}\text { ira } \\
\text { iratus }\end{array}$}} & 18 & 18 & 8 & 28 & 6 \\
\hline & & & 3 & 3 & - & - & - \\
\hline & \multicolumn{2}{|l|}{ irascor } & 1 & - & 2 & 1 & - \\
\hline & \multirow[t]{2}{*}{ Total: } & Absolute & 22 & 21 & 10 & 30 & 6 \\
\hline & & Relative & 1,72 & 1,43 & 1,25 & 1,32 & 0,64 \\
\hline \multirow[t]{5}{*}{$q$} & \multicolumn{2}{|l|}{ precor } & 17 & 17 & 4 & 32 & 11 \\
\hline & \multicolumn{2}{|l|}{ oro } & 3 & - & - & 2 & 2 \\
\hline & \multicolumn{2}{|l|}{ preces } & 2 & 2 & 1 & 13 & 3 \\
\hline & \multirow[t]{2}{*}{ Total: } & Absolute & 22 & 19 & 5 & 47 & 16 \\
\hline & & Relative & 1,71 & 1,29 & 0,62 & 2,12 & 1,72 \\
\hline \multirow[t]{6}{*}{$\mathbf{r}$} & \multirow{2}{*}{\multicolumn{2}{|c|}{$\begin{array}{l}\text { queror, querula } \\
\text { fleo, flebilis, fletus }\end{array}$}} & 2 & 4 & 6 & 6 & 9 \\
\hline & & & 3 & 7 & 7 & 7 & - \\
\hline & \multicolumn{2}{|c|}{ lacrima } & 7 & 11 & 1 & 16 & 4 \\
\hline & \multicolumn{2}{|l|}{ litura } & 1 & 1 & - & 1 & 2 \\
\hline & Total: & Absolute & 13 & 23 & 13 & 30 & 16 \\
\hline & & Relative & 1,01 & 1,56 & 1,62 & 1,32 & 1,72 \\
\hline \multirow[t]{6}{*}{$s$} & \multicolumn{2}{|c|}{ miser } & 16 & 14 & 10 & 17 & 12 \\
\hline & \multicolumn{2}{|c|}{ sollicitus, attonitus } & 2 & 7 & 3 & 3 & 3 \\
\hline & \multicolumn{2}{|c|}{ tristis, infelix } & 10 & 21 & 7 & 20 & 3 \\
\hline & \multicolumn{2}{|c|}{ pudet } & 1 & 3 & 1 & 5 & 7 \\
\hline & \multirow[t]{2}{*}{ Total: } & Absolute & 29 & 45 & 21 & 50 & 25 \\
\hline & & Relative & 2,26 & 3,06 & 2,62 & 2,20 & 2,68 \\
\hline
\end{tabular}

t desero,

$\begin{array}{llllll}\begin{array}{llll}\text { desiderium } \\ \text { procul, longe }\end{array} & 5 & 4 & 5 & 7 & 4 \\ \begin{array}{l}\text { extremus, ultimus } \\ \text { diversus }\end{array} & 11 & 19 & 5 & 14 & 6 \\ \begin{array}{l}\text { peregrinus, } \\ \text { profugus }\end{array} & 2 & 12 & 3 & 11 & 3 \\ \text { Total: Absolute } & 32 & 3 & - & 3 & - \\ \quad \text { Relative } & 2,50 & 2,86 & 2,00 & 1,85 & 1,50 \\ & & 4 & 3 & 7 & 1 \\ \begin{array}{l}\text { imago } \\ \text { oculi mentis }\end{array} & - & 3 & 2 & 8 & - \\ \text { Total: Absolute } & 4 & 1 & - & 4 & 4 \\ \quad \text { Relative } & 0,31 & 0,27 & 0,25 & 0,53 & 0,43\end{array}$




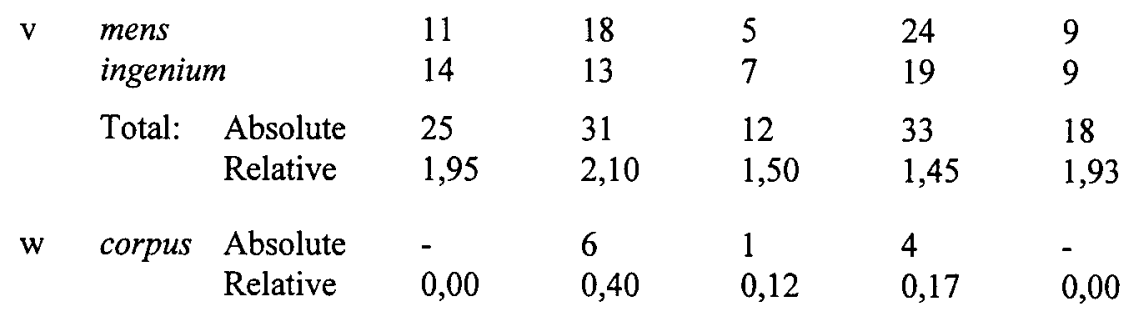

\section{BIBLIOGRAPHY}

Adams, J N 1982. The Latin sexual vocabulary. Baltimore: Johns Hopkins Press.

Ahl, F E 1984. The art of safe criticism in Greece and Rome. AJP 105:14-208.

Ahl, F E 1986. Metaformations: Soundplay and wordplay in Ovid and other classical poets. Ithaca: Cambridge University Press.

Baca, A R 1971. The themes of querela and lacrimae in Ovid's Heroides. Emerita 39:195-201.

Bailey, C (ed) 1921. P. Ovidi Naso Fastorum liber III. Oxford: Clarendon Press.

Barbu, N I et al. (eds) 1976. Ovidianum. Bucharest: Acta Conventus.

Benedum, J 1967. Studien zur Dichtkunst des späten Ovids. Diss. Giessen.

Birnbaum, R 1970. Fatum and Fortuna in Ovid's exile poetry. In Rozelaar, M \& Shimron, B (eds), Commentationes ad antiquitatem classicam pertinentes in memoriam B. Katz, 18-25. Tel Aviv University.

Brunt, P A 1965. Amicitia in the late Roman republic. PCPS n.s. 11:1-20.

Brunt, P A \& Moore, J M 1973. Res Gestae divi Augusti: The achievements of the divine Augustus. 2nd ed. London: Oxford University Press.

Buchan, M 1995. Ovidius imperaramator: Beginnings and endings of love poems and Empire in the Amores. Arethusa 28.1:53-86.

Buescu, V 1958-1959. Trois aspects 'roumains' d'Ovide. In Della Corte 19581959:1.235-247.

Cameron, A 1995. Ancient anagrams. AJP 116.3:477-484.

Claassen, J-M 1986. Poeta, Exul, Vates: A stylistic and literary analysis of Ovid's Tristia and Epistulae ex Ponto. DLit. Diss. University of Stellenbosch.

Claassen, J-M 1989. Carmen and poetics. In Deroux, C (ed), Studies in Roman history and Latin literature 5, 252-266. Collection Latomus 206. Bruxelles: Latomus.

Claassen, J-M 1992. Structure, chronology, tone and undertone: An examination of tonal variation in Ovid's exilic poetry. Akroterion 37(3-4):98-113.

Claassen, J-M 1996. Exile, death and immortality: Voices from the grave. Latomus 55:271-90.

Clay, D 1982. Review of Snyder, Puns and Poetry in Lucretius' de Rerum Natura. AJP 103:226.

Conte, G B 1994. Genres and readers. Trans. G W Most. Baltimore: Johns Hopkins University Press. 
Dant, R 1975. Imago: Untersuchungen zum Bildbegriff der Römer. Bibliothek der Klassische Altertumswissenschaften N.F. ser.2.56. Heidelberg.

Deferrari, R J, Barry, M I, \& Mcguire, M R P [1939] 1969. A concordance of Ovid. Hildesheim: Georg Olms.

D'Elia, S 1958-1959. Lineamenti dell'evoluzione stilistica e ritmica nelle opere ovidiane. In Della Corte 1958-1959:2.377-395.

Della Corte, F (ed) 1958-1959. Atti del Convegno. Rome: Herder.

Deratini, N 1916. Artis rhetoricae in Ovidii carminibus praecipue amatoriis perspicuae, capita quaedam. Diss. Moscow.

Doblhofer, E 1978. Ovids Spiel mit Zweifel und Verzweiflung: Stilistische und litteratur-typologische Betrachtungen zur Tristia und ex Ponto. WJA N.F. 4:121-141.

Doblhofer, E 1980. Ovids Exilpoesie: Mittel, Frucht und Denkmal dichterischer Selbsbehauptung. $A U 23: 59-80$.

Downing, E 1993. Artificial I's: The self as artwork in Ovid, Kierkegaard and Thomas Mann. Tübingen: Niemeyer.

Dragulescu, C 1976. Le vocabulaire psychologique dans les. Héroides. In Barbu 1976:255-265.

Eichert, O 1904. Wörterbuch zu den Verwandlungen des Publius Ovidius Naso. Hannover \& Leipzig: Hahnsche Buchhandlung.

Fasciano, D \& Leblanc, P 1973. Le numen chez Ovide. RCCM 15:257-296.

Ferguson, J 1978. Notes on some uses of ambiguity and similar effects in Ovid's Amores book 1. LCM 3:121-132

Focardi, G 1975. Difesa, preghiera, ironia nel II libro dei Tristia di Ovidio. SIFC 47:86-129.

Green, P 1981. Wit, sex and topicality: The problems confronting a translator of Ovid's love poetry. EMC 30:79-96.

Green, P 1994. The poems of exile. Harmondsworth: Penguin Books.

Hellegouarc'h, J 1963. Le vocabulaire latin des relations et des partis politiques sous la République. Paris: Les Belles Lettres.

Hellegouarc'h, J 1976. Aspects stylistiques de l'expression de la tristesse et de la doleur dans les poèmes de les poèmes ovidiens de l'exil. In Barbu 1976:325340.

Helzle, M 1988. Ovid's Poetics of Exile. ICS 13:73-83.

Kajanto, I 1957. God and fate in Livy. Turku (Finland): Turun Yliopisto (Kustantama).

Kajanto, I 1961. Ovid's conception of fate. Turku: Turun Yliopisto.

Kenney, E J 1973. The style of the Metamorphoses. In Binns, J W (ed), Ovid, 116123. London: Routledge and Kegan Paul.

Lateiner, D 1990. Mimetic syntax: Metaphor from word order, especially in Ovid. AJP 111:204-237

Leach, E W 1993. Absence and desire in Cicero's De Amicitia. CW 87:3-20.

Lieberg, G 1980. Ovide et les Muses. LEC 48:3-22.

Lueneberg, A 1901. De Ovidio sui imitatore. Diss. Berlin. 
Melville, A D (trans.) \& Kenney, E J (introduction \& notes) 1992. Sorrows of an exile. Oxford: Clarendon Press.

Maltby, R 1991. A lexicon of ancient etymologies. Leeds: Francis Cairns.

Micu, J 1981. Pontus Euxinus in opercle Ovidiene din exil. Pontica 14:317-327.

Nagle, B R 1980. The poetics of exile: Program and Polemic in the Tristia and Epistolae ex Ponto of Ovid. Collection Latomus 170. Bruxelles: Latomus.

Németh, B 1980. Caelestia sacra: Zur Frage des Ovidischen Selbsbewusstseins. Acta Classica Universitatis Scientiarum Debreceniensis 19:67-75.

Newman, J K 1967. Augustus and the new poetry. Collection Latomus 88. Bruxelles: Latomus.

Osmun, G F 1983. Desistas lacrimare: Tears in Latin elegy. $C B$ 60:45-47.

Oton, S 1976. Sobre Tristia 1.1. Durius 4:141-155.

Packard Humanities Institute 1991. PHI CD ROM \#5.3. Latin texts; Bible versions. California: Los Altos.

Pichon R 1902. De Sermone Amatorio apud Latinos elegiarum scriptores. Paris.

Pippidi, D M 1931. Le numen Augusti: Observations sur une forme occidentale du culte impérial. $R E L$ 9:83-111.

Pippidi, D M 1972. In jurul cronologiei scrisorilor lui Ovidiu din Pont (with German summary). Pontica 5:419-428.

Poznanski, L 1978. A propos de la droite et la gauche chez Ovide. SCI 4:50-62.

Purnelle-Simart, A \& Purnelle, G 1987. Ovide: Ars Amatoria, Remedia Amoris, De medicamine: Index verborum, listes de fréquence, Relevés grammaticanx. Liege: Centre Informatique de Philosophie et Lettres.

Rogers, R S 1959. The emperor's displeasure - amicitiam renuntiare. TAPA 90:224237.

Rogers, R S 1966. The emperor's displeasure and Ovid. TAPA 97:373-78.

Scott, K 1930. Emperor-worship in Ovid. TAPA 61:43-69.

Sharrock, A 1995. The drooping rose: Elegiac failure in Amores 3.7. Ramus 24:152180.

Snyder, J M 1980. Puns and poetry in Lucretius' De Rerum Natura. Amsterdam: Grüner.

Soraci, G 1980. Il lessico della lontenanza in Ovidio. In Atti III Convegno naz di Pedag Francavilla, 3-12. L'Aquila Ist. di Lingue e Lett. Class.

Stoessl, F 1970. Ovids Lebentscheidung. In Ableitinger, D \& Gugel, H (eds), Festschrift Vretska, 250-275. Heidelberg: Winter.

Syme, R 1979. Imperator Caesar: A study in nomenclature. In Badian, E (ed), Roman papers, 361-366. Oxford: Clarendon Press.

Taylor, L R 1931. The divinity of the Roman emperor. APA Monograph 1. Cambridge, Mass.: American Journal of Philology.

Thibault, J C 1964. The mystery of Ovid's exile. Berkeley \& Los Angeles: University of California Press.

Tracey, V A 1978-1979. Ovid's self-portrait in the Amores. Helios 6:57-62.

Verdière, $\mathrm{R}$ 1992. Le secret du voltigeur d'amour ou le mystère de la relégation d'Ovide. Collection Latomus 218. Bruxelles: Latomus. 
Viarre, S 1974. L'image et le symbole dans la poésie d'Ovide. Recherches sur l'imaginaire. $R E L$ 52:263-280.

Videau-Delibes, A 1991. Les Tristes d'Ovide et l'élégie romaine. Paris: Klincksieck.

Vincent, M 1994. Between Ovid and Barthes: Ecphrasis, orality, textuality in Ovid's Arachne. Arethusa 27.3:361-386.

Watson, LC 1982. Ovid Amores 1.6: A parody of a hymn? Mnemosyne 35:92-102.

Wheeler, SM 1995. Imago mundi: Another view of the creation in Ovid's Metamorphoses. AJP 116.1:95-122.

Zumwalt, N 1977. Fama subversa: Theme and structure in Ovid Metamorphoses 12.39-63. CSCA 10:209-222. 